\title{
The Market Reaction To Voluntary Stock Option Expense Recognition Announcements
}

Ronald Best, (E-mail: rbest@westga.edu), State University of West Georgia Bing-Xuan Lin, (E-mail: bli4962u@ postoffice.uri.edu), University of Rhode Island Joseph Rue, (E-mail: jrue@ fgcu.edu), Florida Gulf Coast University Ara Volkan, (E-mail: avolkan@ @gcu.edu), Florida Gulf Coast University

\begin{abstract}
Recently, numerous firms announced that they would voluntarily begin recognizing the SFAS 123 expense. We use standard event-study methodology and regression analysis to analyze the equity valuation effects of these announcements. SFAS 123 requires firms to calculate the fair value of stock options granted but allows firms to either recognize the expense in their income statements or simply disclose the impact on net income in financial statement footnotes. Our results reveal statistically significant positive abnormal announcement period returns for the full sample of firms analyzed, with results mainly driven by firms that are early (July or August 2002 announcements) announcers. In addition, regressions confirm a significant negative relationship between the size of the stock option expense and the abnormal announcement returns.
\end{abstract}

\section{Introduction}

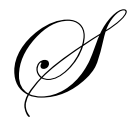

tatement of Financial Accounting Standards No. 123 (SFAS 123) requires firms to calculate the fair value of stock options granted but allows firms to either recognize the expense in their income statements or simply disclose the impact on net income in financial statement footnotes (FASB 1995). Until recently only a few firms chose to recognize the expense. However, in the summer of 2002 numerous firms announced that they would voluntarily begin recognizing SFAS 123 expense. The voluntary actions of these firms lead us to question why firms suddenly chose to begin recognizing the expense and what benefit they expected in return.

Theoretically, the impact of these announcements is debatable since the calculated expense is disclosed to market participants whether or not it is recognized. Given the availability of the calculated expense, it is possible that the announcements of expense recognition do not provide incremental information to investors and may represent non-events. If this line of reasoning is correct, the recognition announcements should result in no equity valuation effects. On the other hand, it is reasonable to assert that firms make decisions that are in their best interests, suggesting that announcements of recognition of stock option expense will be made when benefits of recognition exceed costs.

We focus our investigation on the reaction of market participants to firms' decisions to recognize stockbased compensation expense. We use standard event-study methodology and regression analysis to analyze abnormal announcement-period returns. Our results reveal statistically significant positive abnormal announcementperiod returns for the full sample of firms announcing recognition of stock option expenses. However, the regressions confirm that these results are driven by the positive market reactions to expense recognition announcements accruing to those firms that are early (July or August 2002 announcements) announcers. Regressions also show a significant negative relationship between the size of the stock option expense and the abnormal announcement returns. These results confirm some of the findings by Aboody, Barth, and Kasznik (May 2004) and by Robinson and Burton (2004). 


\section{Accounting Treatment of Stock Option Expense}

The Financial Accounting Standard Board (FASB) issued SFAS 123 in 1995 after more than a decade of deliberations. Although the exposure draft of the SFAS indicated that stock option amounts should be recognized as an expense, political pressure led the FASB to modify the proposal. The result was that SFAS 123 encouraged companies to adopt a fair vale pricing model to measure and recognize the option value at the grant date and record a portion of this amount as annual expense over the vesting period of the option. However, it allowed firms to choose not to recognize the expense but instead simply disclose the pro forma impact of the fair value of options on their annual earnings and earnings per share in the footnotes of their annual reports. Until recently few firms chose to recognize stock option expense, but beginning in the summer of 2002 a large number of firms announced that they will do so.

During the same time frame, the FASB continued to consider the stock option expense issue and in December 2002 the SFAS 148 was issued to amend the transition provisions and footnote disclosure rules of SFAS 123 (FASB 2002). The amendments to footnote disclosures extended the SFAS 123 requirements to interim periods. Also, on April 2004, the International Accounting Standards Board (IASB) issued an International Financial Reporting Standard (IFRS) on shared-based payments that required the use of fair values to measure and expense all such transactions (IASB 2004). Finally, on March 31, 2004, the FASB issued an exposure draft (ED) that will eliminate the non-recognition or footnote disclosure approach to accounting for stock option costs (FASB 2004). The FASB aims to complete its work on final standards in late 2004 (KPMG 2004), promoting international harmonization and convergence in accounting for share-based compensation.

Many argue that while the FASB and the IASB are on the right track in requiring the recognition of stock option expenses, their proposals do not address all controversies (Best, Rue, and Volkan 2002; Financial Accounting Standards Committee of the AAA 2004; Kirschenheiter, Mathur, and Thomas 2004). These critics recommend that both the FASB and the IASB abandon the static option valuation and expensing procedures they support and adopt a dynamic model of periodic revaluation of options by marking the value of options to market at the financial statement dates (Hull and White 2004). In addition, the critics argue that market based measurement and recognition of option costs must continue after the service or vesting period ends and until the options are either exercised or expire, ensuring that both the total amount of wealth that has been transferred from stockholders to executives and the amount that could be transferred in the future are reported in the financial statements (Briloff 2003; Rue, Volkan, Best, and Lobo 2003; Deshmukh, Howe, and Luft 2004).

\section{Potential Benefits of Stock Option Expense Recognition}

The continuing debate surrounding the recognition of stock option expense is interesting since conventional wisdom holds that as long as calculated stock-option expense is disclosed to market participants, announcements of expense recognition should not provide incremental information to investors. Support for this contention is found in Aboody, Barth, and Kasznik (April 2004) who report a significant negative relationship between share prices/returns and unrecognized SFAS 123 expense which indicates that market participants consider the reported but unrecognized expense when valuing firms.

However, the sudden rush to voluntary recognition of the expense by numerous firms is indicative of perceived benefits [e.g., Holthausen and Leftwich (1983); Fields, Lys, and Vincent (2001)]. In this regard, it is interesting to note that the announcements of voluntary recognition began in earnest in the summer of 2002 and coincided with high profile financial reporting scandals concerning firms such as Enron and WorldCom. Also, during this time, debate intensified regarding the appropriateness of the expensing of stock-based compensation, with many market participants indicating a preference for recognition of the expense. Further, many of the proponents of stock-based compensation expense recognition suggested that recognition could increase earnings transparency thereby decreasing information asymmetry and increasing the confidence of market participants in the financial reports of the firms. For example, Warren Buffet, CEO of Berkshire Hathaway, Inc., argued that firms that voluntarily recognized the expense would develop a reputation for being believable (Business Week, July 29, 2002). 
These observations imply that announcements of expense recognition draw attention to the firms and serve as a signal of quality financial reporting. The announcements may also indicate the firms' commitments to costeffective stock-based compensation plans and generally conservative accounting choices. Possible benefits of such signals are shown by Hughes and Levine (2003) who develop a model in which firms that commit to conservative accounting choices credibly convey favorable information about future cash flows. Lower quality firms would not likely mimic higher quality firms in recognizing these expenses since recognition is costly to the firms due to its is irreversible nature and negative impact on net income relative to the disclosure alternative. The latter is particularly important since many covenants and contracts have earnings based thresholds that are costly to violate (DeFond and Jiambalvo 1994; Sweeney 1994).

While, in 2002, many market participants began to associate stock-option expense recognition with increased earnings quality, several popular financial press outlets started to focus on stock based compensation and its effects. For example, the link between recognition of stock option expense and possible benefits such as perceived earnings quality, acknowledgment of the level of stock options used, and enhanced reputation is discussed in an article by Business Week (July 29, 2002, p. 46) entitled "To Expense or Not to Expense." The main premise of the article is that less-hyped earnings figures will boost investor confidence.

Thus, the increased focus on recognition of stock-option expense and the discussion of possible benefits may have motivated firms to act. Whether the potential benefits translated into positive firm valuation effects is an empirical question. We examine this question in the following sections of the paper by identifying firms that announce the recognition of stock-option expense and calculating the resulting equity valuation effects.

\section{Sample}

We used the Lexis/Nexis database to search all available newswire services for firms that announced recognition of stock option expense during the years 2002 and 2003. The search yielded 135 firms for which we could identify announcement dates. We also checked whether additional information was released concurrent with the expense recognition announcement, to analyze confounding effects.

Individual firm stock return and stock index return information is gathered from the Center for Research in Security Prices (CRSP) database. Additional firm data is gathered from the COMPUSTAT database, with all variables measured as of the end of the fiscal period preceding the expense recognition announcement. Means, medians, minimums, and maximums are calculated for selected variables for 135 firms announcing expensing of stock options during the period from 2002 to 2003. Total assets, net income, and market value of equity (calculated as stock price multiplied times common shares outstanding) are collected to provide measures of size and profitability. These variables are important for cross-sectional analysis since various studies of market reactions indicate possible size effects.

Since resolution of information asymmetry is one postulated benefit of announcing stock option expense recognition, we retrieve information on institutional stock ownership which represents the percentage of a firm's aggregate number of shares outstanding held by institutions. Stock price is the closing stock price at the end of the fiscal year preceding the announcement. Finally, we collect the stock option expense from the COMPUSTAT database. This option expense variable indicates the fair value effect of stock options on earnings per share.

Table 1 shows descriptive statistics for the sample of firms. The average of total assets is $\$ 68,767$ million with a median value of $\$ 8,109$ million. Average market value of equity is $\$ 21,603$ million with a median value of $\$ 3,177$ million. Stock prices range from a low of $\$ 1.96$ to a high of $\$ 666.75$ with a mean value of $\$ 32.72$. Shares held by institutions as a percentage of total share outstanding range from zero to 36.70 percent, with a mean value of 4.13 percent. Finally, the COMPUSTAT calculated fair value effect of stock options on earnings per share average $\$ 0.12$ with a median value of $\$ 0.06$. 
Table 1. Descriptive Statistics for Selected Variables

\begin{tabular}{lllll}
\hline Characteristic & Mean & Median & Minimum & Maximum \\
Total assets (millions of \$\$) & 68767.27 & 8109.14 & 31.72 & 1051450.00 \\
MV of equity (millions of \$\$) & 21603.14 & 3176.61 & 2.91 & 397831.60 \\
Net income (millions of \$) & 785.37 & 60.31 & -5453.00 & 4126.00 \\
Stock Price (\$) & 42.70 & 32.72 & 1.96 & 666.75 \\
Institutional holdings (\%) & 4.13 & 3.87 & 0.00 & 36.70 \\
Option expense/share (\$) & 0.12 & 0.06 & 0.00 & 1.02 \\
\hline
\end{tabular}

\section{Methodology and Results}

Standard event-study methodology as described in Brown and Warner (1985) is used to calculate announcement period abnormal returns. For each event we define day 0 as the date of the newswire article containing the announcement of the intent to recognize stock option expense and day 1 as the following day. The announcement period is defined as day 0 and day 1 . The two days are used since it is not always possible to determine whether the announcement on day zero occurred prior to the end of trading on that day. Cumulative abnormal returns for the announcement period are market model prediction errors for day 0 and day 1 . The market model parameters are estimated using ordinary-least-squares-regressions over the time period beginning 270 trading days before the announcement and ending 15 days before the announcement. The CRSP equal-weighted stock index is used as the market proxy.

Table 2 contains the results of the event-study analysis. Panel A of Table 2 shows that the mean abnormal announcement period return for the full sample of firms is positive $0.7433 \%$, which is statistically different from zero at the $1 \%$ (99\% confidence) level. However, a large number of firms released additional information concurrently with the announcement of recognition of stock option expense. Also, several members of the Financial Services Forum (FSF) announced their decisions to expense stock options simultaneously. Since concurrent information release and simultaneous industry release could affect the announcements, Panel B of Table 2 separates the firms into three categories: (1) firms with no concurrent information release; (2) firms with concurrent information release; and (3) FSF member firms that simultaneously announce their decisions. While the members who announce before that time were not removed from the sample, their removal would not materially affect the results.

Panel B of Table 2 shows that FSF members exhibit an average abnormal announcement period return that is statistically indistinguishable from zero $(0.0128 \%)$. The mean abnormal announcement return for firms with concurrent information releases is $1.0483 \%$ which is statistically different from zero at the $1 \%$ (99\% confidence) level. Firms with no concurrent information releases exhibit a smaller positive mean abnormal return of $0.6311 \%$ which is not significantly different from zero at conventional levels (confidence levels of $95 \%$ or more). Although this result suggests that stock-option expense recognition may not yield significant stock price reactions, further analysis is required.

An examination of the sample firms indicates that 77 of the firms' announcement dates occur in July and August 2002. Since it is logical that firms who expect the greatest benefit from announcing will do so first, we further divide the sample into early and late announcers. For example, popular press discussions of stock-option expense recognition announcement by Coke espouse this opinion. In nearly all news releases, Coke is characterized as a marginal user of options, with a relatively easy decision to look bold and make the switch to expense recognition (Business Week, July 29, 2002).

Our reported results are based on defining early announcers as those firms announcing recognition of stockoption expense in July and August of 2002. We also estimate results defining early announcers as those firms announcing expense recognition within one or two months of the date of the very first recognition announcement, which was made in mid-July, 2002. The results are similar regardless of the definition used. We exclude the FSF 
firms who simultaneously announce from this analysis. Panel $\mathrm{C}$ of Table 2 shows that early announcers exhibit positive abnormal announcement period returns that are significantly different from zero regardless of whether or not concurrent information is released. The mean abnormal return for early announcers with no concurrent information release is $1.7835 \%$ while the mean abnormal return for those with concurrent information is $1.8558 \%$.

Table 2. Abnormal Announcement Period Returns for Firms Announcing Stock Option Expensing

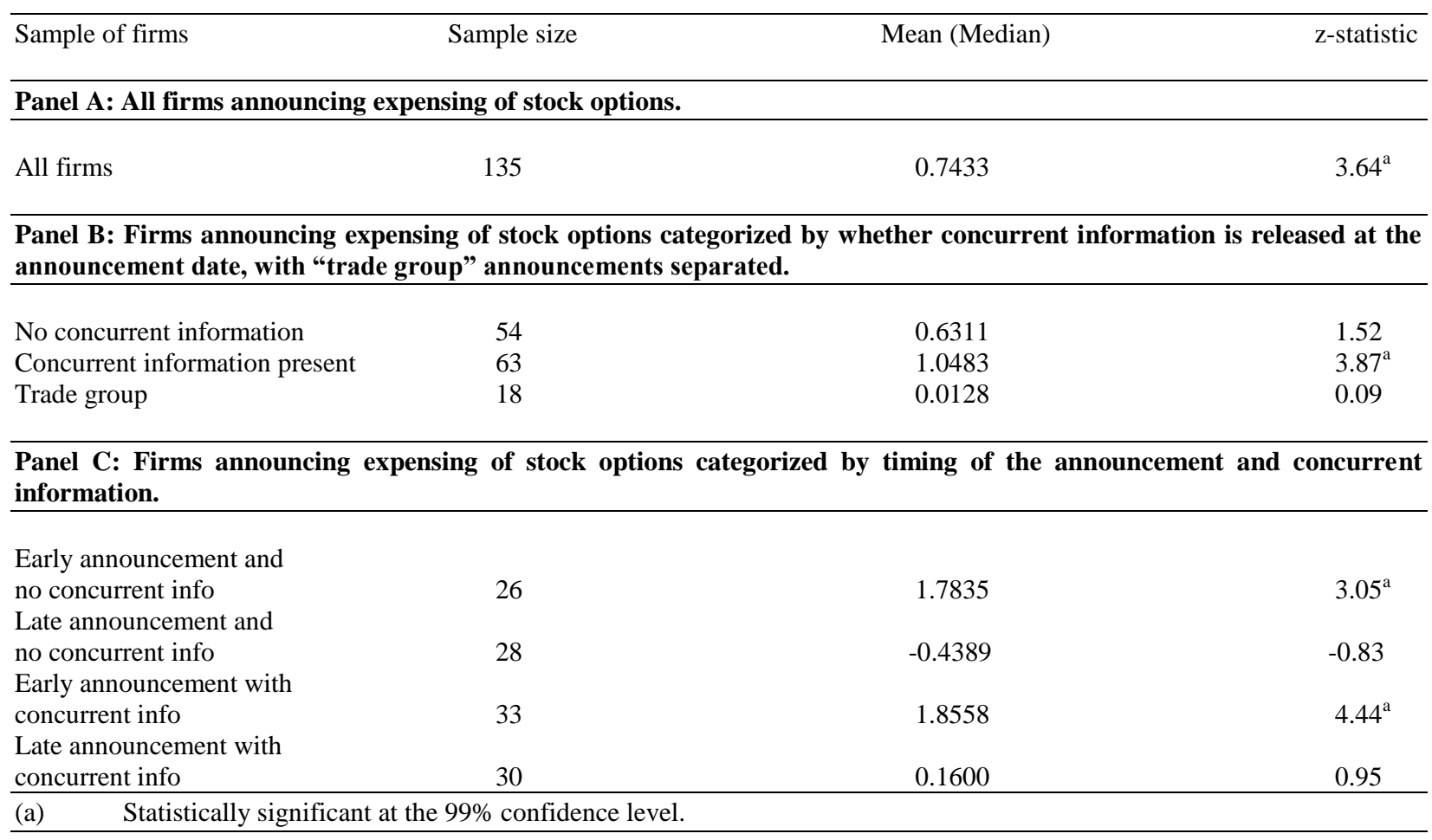

On the contrary, late announcers exhibit abnormal announcement period returns that are not statistically different from zero. The mean abnormal return for late announcers with is $-0.4389 \%$ while the mean abnormal return for late announcers with concurrent information is $0.1600 \%$. Further, difference-in-mean tests show that the differences in mean abnormal returns to early and late announcers are statistically significant.

These results appear consistent with the view that market participants consider early announcers' stock option expense recognition decisions to be positive signals. The evidence lends credence to the proposition that the announcements indicate the firms' commitments to cost-effective stock-based compensation plans and generally conservative accounting choices. On the other hand, late announcers' decisions are not accepted as positive signals by market participants and contain no significant information. Apparently, market participants believe that these firms either base their decisions on the belief that expense recognition will become mandatory in the future or are mimicking the early announcers.

To further examine possible determinants of the abnormal announcement period returns, we estimate regressions for the 117 sample firms that individually announced their decision to expense stock options (18 firms were FSF members), with the two-day abnormal announcement period returns as dependent variables and various firm data as explanatory variables. As it was the case for the analysis of the entire sample, individual firm stock return and stock index return information is gathered from the CRSP database and additional firm data is gathered from the COMPUSTAT database, with all variables measured as of the end of the fiscal period preceding the expense recognition announcement. 
The independent variables include the log of each firm's market value of equity (MVE), the percentage of shares held by institutional investors ( $\mathrm{IH} \%)$, an indicator variable that identifies whether a firm is an early announcer (E), the impact of stock option expense on earnings per share (EPSI) calculated by COMPUSTAT using fair values, and an indicator variable indicating whether concurrent information is released at the time of the stock option expense recognition announcement (CI). All test statistics are computed using White's (1980) heteroscedasticityconsistent covariance matrix.

The natural log of the MVE is included as a measure of firm size, with similar results obtained when the natural logarithm of total assets is used as the firm size proxy. We control for size since larger firms may have greater pre-existing reputation capital with investors that will affect the reaction to new announcements. The $\mathrm{IH} \%$ is included as a measure of information asymmetry. The presumption is that greater institutional holdings result in more monitoring and less information asymmetry. The indicator variable $\mathrm{E}$ is included that equals one for firms designated as early announcers (announcement is made in July or August 2002), and zero otherwise. The EPSI is included since it is likely that the market reaction is related to the size of the option expense recognized. Finally, CI is included that equals one for firms with additional information released concurrently with the expense recognition announcement, and zero otherwise.

Regression results are shown in Table 3. Regression (1) includes all independent variables except the concurrent information (CI) indicator variable. The coefficient for institutional holdings (IH\%) is 0.04 and it is not significantly different from zero. This suggests that information asymmetry differences are not driving the returns. The coefficient for MVE is 0.34 which is significantly different from zero at the $10 \%$ ( $90 \%$ confidence) level, indicating that the market reaction to expense recognition announcements is more positive for larger firms. The coefficient for early announcers (E) is 1.86 and it is significantly different from zero at the 5\% (95\% confidence) level. This result indicates that early announcers exhibit an announcement period abnormal return that is $1.86 \%$ larger than that of late announcers, confirming that event study analysis was warranted. The option expense (EPSI) coefficient is -3.91 which is significantly different from zero at the 5\% (95\% confidence) level. This indicates that the abnormal announcement period return is reduced for firms with larger stock option expense and that recognition in financial statements is superior to footnote disclosure since market participants do perceive a cost associated with stock option expense recognition. Regression (2) reveals that the estimated coefficient of the concurrent information indicator variable is not significantly different from zero and that its inclusion has little effect on the magnitude and statistical significance of the other variables.

Table 3. Regression Results for 117 Firms Announcing Stock Option Expensing (z-statistic in parenthesis)

\begin{tabular}{lll}
\hline Variable & Regression (1) & Regression (2) \\
\hline Intercept & $-2.00(1.15)$ & $-2.45(1.50)$ \\
MVE & $0.34\left(1.76^{\mathrm{c}}\right)$ & $0.36\left(1.92^{\mathrm{c}}\right)$ \\
$\mathrm{IH} \%$ & $-0.04(0.49)$ & $-0.04(0.49)$ \\
E & $1.86\left(2.05^{\mathrm{b}}\right)$ & $1.83\left(2.14^{\mathrm{b}}\right)$ \\
EPSI & $-3.91\left(2.18^{\mathrm{b}}\right)$ & $-4.01\left(2.12^{\mathrm{b}}\right)$ \\
CI & & $0.62(0.73)$ \\
Adjusted $\mathrm{R}^{2}$ & 0.0487 & 0.0438 \\
\hline
\end{tabular}

(b) Statistically significant at the $95 \%$ confidence level.

(c) Statistically significant at the $90 \%$ confidence level.

\section{Conclusions}

We investigate the market reaction to firms' decisions to recognize stock-based compensation expense. The SFAS 123 requires firms to calculate the fair value of stock options granted but allows firms to either recognize the expense in their income statements or simply disclose the impact on net income in financial statement footnotes. After the SFAS 123 was issued, only a few firms chose to recognize the expense. However, in the summer of 2002 numerous firms announced that they would voluntarily begin recognizing SFAS 123 expense. This raises the question of whether the decision to voluntarily recognize stock option expense affects firms' values.

We examine the issue by calculating the stock price reaction to announcements of recognition of stockbased compensation expense. We use standard event-study methodology and regression analysis to analyze abnormal announcement period returns. Our results indicate that some firms do experience abnormal stock price 
reactions upon announcing recognition of stock option expense. However, the results are driven by the positive market reactions to expense recognition announcements that accrue to firms that are early announcers, with late announcers accruing no benefit. We also find a significant negative relationship between the size of the stock option expense and the abnormal announcement returns, indicating that stock options have material costs and recognition approach to accounting for stock options is superior to footnote disclosure. Thus, the time, money, and effort spent by the FASB and the IASB to revise the SFAS 123 and to achieve international harmonization have merit.

\section{Suggestions for Future Research}

Future research could focus on the cross-sectional differences between the characteristics of those firms that recognized stock option expense versus firms that opted for footnote disclosure only. In addition, one could examine the differences between the size of the option expense and its impact on the financial measures of firms announcing expense recognition versus firms that did not. Finally, event studies concerning industry counterparts could be conducted to examine the reaction of market participants to those firms in a given industry that recognized option expense versus those that did not.

\section{References}

1. Aboody, D., M. E. Barth, and R. Kasznik, "Firms' Voluntary Recognition of Stock-Based Compensation Expense," Journal of Accounting Research (May 2004), pp. 123-150.

2. Aboody, D., M. E. Barth, and R. Kasznik, "SFAS 123 Stock-Based Compensation Expense and Equity Market Values," The Accounting Review (April 2004), pp. 251-275.

3. Best, R., J. Rue, and A. Volkan, "Impact of Stock Options on Quarterly EPS: A Proposal for Change," International Business and Economics Research Journal (Winter 2002), pp. 73-82.

4. Briloff, A., "Accounting for Stock Options,” The CPA Journal (December 2003), pp. 12-15.

5. Brown, S. J., and J. B. Warner, "Using Daily Stock Returns: The Case of Event Studies," Journal of Financial Economics (March 1985), pp. 3-32.

6. DeFond, M. L., and J. Jiambalvo, "Debt Covenant Violation and Manipulation of Accruals," Journal of Accounting and Economics, Vol. 17 (1994), pp. 145-176.

7. Deshmukh, S., K. M. Howe, and C. Luft, "Stock Option Expensing and Corporate Governance: When Will the Debate End?" Strategic Finance (July 2004), pp. 41-44.

8. Fields, T. D., T. Z. Lys, and L. Vincent, "Empirical Research on Accounting Choice," Journal of Accounting and Economics, Vol. 31 (2001), pp. 255-307.

9. Financial Accounting Standards Board, Statement of Financial Accounting Standards No. 123: Accounting for Stock-Based Compensation, FASB, Norwalk, CT., 1995.

10. Financial Accounting Standards Board, Statement of Financial Accounting Standards No. 148: Accounting for Stock-Based Compensation-Transition and Disclosure, FASB, Norwalk, CT, 2002.

11. Financial Accounting Standards Board, Exposure Draft: Share-Based Payment: An Amendment of Statements No. 123, 148, and 95, FASB, Norwalk, CT., 2004.

12. Financial Accounting Standards Committee of the American Accounting Association, "Evaluation of the IASB's Proposed Accounting and Disclosure Requirements for Share-Based Payment," Accounting Horizons (March 2004), pp. 65-76.

13. Holthausen, R. W., and R. W. Leftwich, "The Economic Consequences of Accounting Choice: Implications of Costly Contracting and Monitoring," Journal Accounting and Economics, Vol. 5 (1983), pp. 77-118.

14. Hughes, J. S. and C. B. Levine, "Management Compensation and Earnings-Based Covenants in Resolving Adverse Selection in Credit Markets," Journal of Applied Corporate Finance (2004), Forthcoming.

15. Hull, J., and A. White, “Accounting for Employee Stock Options: A Practical Approach to Handling the Valuation Issues," Journal of Derivatives Accounting, Vol.1 (2004), pp. 3-9.

16. International Accounting Standards Board, IFRS 2: Share-Based Payment, IASB, London, 2004.

17. Kirschenheiter, M., M. Rohit, and J. K. Thomas, “Accounting for Employee Stock Options," Accounting Horizons (June 2004), pp. 135-156.

18. KPMG LLP, Inc., "Expensing Stock Options Gets Crystallized,” Defining Issues (March 2004), pp. 1-6. 
19. Robinson, D., and D. Burton, "Discretion in Financial Reporting: The Voluntary Adoption of Fair Value Reporting for Employee Stock Options," Accounting Horizons (June 2004), pp. 97-108.

20. Rue, J., A. Volkan, R. Best, and G. Lobo, "Stock Options Revisited," The CPA Journal (November 2003), pp. 34-40.

21. Sweeney, A. P., "Debt-Covenant Violations and Managers' Accounting Responses," Journal of Accounting and Economics, Vol. 17 (1994), pp. 281-308.

22. White, H., "Heteroskedasticity-Consistent Covariance Matrix Estimator and a Direct Test for Heteroskedasticity," Econometrica, Vol. 48 (1980), pp. 817-838.

Notes 